\title{
A Chiral Three Dimensional Potassium(I)/Strontium(II)/Chromium(III) Oxalato-Bridged Coordination Polymer: Synthesis, Characterization and Thermal Analysis
}

\author{
Justin Nenwa1 ${ }^{*}$, Issoufou Kaboré1, Yves A. Mbiangué2, Patrick L. Djonwouo1, \\ Peter T. Ndifon ${ }^{1}$ \\ ${ }^{1}$ Department of Inorganic Chemistry, University of Yaounde 1, Yaounde, Cameroon \\ ${ }^{2}$ Chemistry Department, Higher Teachers' Training College, University of Maroua, Maroua, Cameroon \\ Email: ${ }^{*}$ inenwa@yahoo.fr
}

Received 11 october 2014; revised 8 november 2014; accepted 26 november 2014

Copyright (C) 2014 by authors and Scientific Research Publishing Inc.

This work is licensed under the Creative Commons Attribution International License (CC BY).

http://creativecommons.org/licenses/by/4.0/

(c) (i) Open Access

\begin{abstract}
A new compound of general formula $\left\{\left[\left(\mathrm{H}_{2} \mathrm{O}\right)_{2} \mathrm{~K}\left(\mu-\mathrm{H}_{2} \mathrm{O}\right) \operatorname{Sr}\right] @\left[\mathrm{Cr}\left(\mathrm{C}_{2} \mathrm{O}_{4}\right)_{3}\right]\right\}_{\mathrm{n}}(1)$ has been synthesized in water and characterized by elemental and thermal analyses, EDX, IR and UV-Vis spectroscopies and by single crystal $X$-ray structure determination. Compound 1 crystallizes in the chiral space group Fdd2 of orthorhombic system with $a=14.110$ (4) $\AA, b=36.074$ (11) $\AA$, $c=11.034$ (3) $\AA$ and $Z$ $=16$. Compound 1 is a coordination polymer in which the three-dimensional lattice framework is realized by the interconnectivity between $\mathrm{K}^{+}$cations, $\mathrm{Sr}^{2+}$ cations, aqua ligands and $\left[\operatorname{Cr}\left(\mathrm{C}_{2} \mathrm{O}_{4}\right)_{3}\right]^{3-}$ complex anions. The asymmetric unit of 1 consists of one cationic motif formally written $\left[\left(\mathrm{H}_{2} \mathrm{O}\right)_{2} \mathrm{~K}\left(\mu-\mathrm{H}_{2} \mathrm{O}\right) \mathrm{Sr}\right]^{3+}$ and one anionic entity, $\left[\mathrm{Cr}\left(\mathrm{C}_{2} \mathrm{O}_{4}\right)_{3}\right]^{3-}$. The $\mathrm{K}^{+}$and $\mathrm{Sr}^{2+}$ ions in the cationic motif are both eight-coordinate while the $\mathrm{Cr}^{3+}$ ions in the anionic complex are six-coordinate in a distorted octahedral geometry. Coulombic interactions between the ionic motifs and the three-dimensional H-bonding involving aqua ligands help to consolidate the bulk structure. Thermogravimetric analysis (TGA) shows that compound 1 is stable to heat up to $c a .80^{\circ} \mathrm{C}$.
\end{abstract}

\section{Keywords}

Tris(Oxalato)Chromate(III) Anion, Heterometallic Complex Polymer, Chiral Compound, Crystal

*Corresponding author.

How to cite this paper: Nenwa, J., Kaboré, I., Mbiangué, Y.A., Djonwouo, P.L. and Ndifon, P.T. (2014) A Chiral Three Dimensional Potassium(I)/Strontium(II)/Chromium(III) Oxalato-Bridged Coordination Polymer: Synthesis, Characterization and Thermal Analysis. Crystal Structure Theory and Applications, 3, 67-75. http://dx.doi.org/10.4236/csta.2014.34008 


\section{Structure, Thermal Stability}

\section{Introduction}

One of the current research activities in the field of materials science is unarguably the rational design and synthesis of heterometallic complexes with interesting molecular topologies, crystal packing motifs and potential applications as advanced multifunctional materials [1]-[6]. In this respect, the old but evergreen oxalate dianion, $\mathrm{C}_{2} \mathrm{O}_{4}{ }^{2-}$, with its $\pi$-extended system together with its ability to transmit relatively large magnetic interactions between the metal ions that it bridges, provides unique opportunities for the discovery of unusual networks in this fascinating and challenging field [7]-[9].

In our research group, we recently have been interested in the design and construction of polymetallic oxalatebased architectures by following the so-called "complex-as-ligand approach". In this synthetic strategy, a molecular building block, the homoleptic $\left[\mathrm{M}^{\mathrm{III}}\left(\mathrm{C}_{2} \mathrm{O}_{4}\right)_{3}\right]^{3-}$ tris(oxalato)metalate(III) octahedral complex is used as a ligand towards the divalent $\mathrm{Ba}^{2+}$ cations to generate 3-D polymeric complexes of general formula, $\left\{\mathrm{Ba}_{6}\left(\mathrm{H}_{2} \mathrm{O}\right)_{17}\left[\mathrm{M}^{\mathrm{III}}\left(\mathrm{C}_{2} \mathrm{O}_{4}\right)_{3}\right]_{4}\right\} \cdot 7 \mathrm{H}_{2} \mathrm{O}(\mathrm{M}=\mathrm{Cr} ; \mathrm{Fe})[10]$ [11], with the ionic ratio of $3 \mathrm{Ba}^{\mathrm{II}} \mathrm{vs} \mathrm{M}^{\mathrm{III}}$. This family of complexes, indeed, has proven to be a useful precursor for the synthesis of highly versatile materials with the potential of accumulating within a single system a whole set of relevant functionalities, such as nanoscale structural features [12] [13], extended hydrogen bonding and magnetic interactions [14] [15]. Furthermore, introducing chirality into these materials may give place to potential applications in research fields such as chiral spintronics or magneto-chiral dichroism [16].

In the course of a systematic search for new members of this interesting family of heterometallic complexes involving oxalate dianions, we herein report the synthesis, crystal structure and thermal behavior of a chiral three-dimensional oxalato-bridged coordination polymer, $\left\{\left[\left(\mathrm{H}_{2} \mathrm{O}\right)_{2} \mathrm{~K}\left(\mu-\mathrm{H}_{2} \mathrm{O}\right) \mathrm{Sr}\right] @\left[\mathrm{Cr}\left(\mathrm{C}_{2} \mathrm{O}_{4}\right)_{3}\right]\right\}_{\mathrm{n}}(\mathbf{1})$, obtained from a metathesis reaction in water of the $\mathrm{K}_{3}\left[\mathrm{Cr}\left(\mathrm{C}_{2} \mathrm{O}_{4}\right)_{3}\right] \cdot 3 \mathrm{H}_{2} \mathrm{O}$ and $\mathrm{SrCl}_{2}$ salts with the stoichiometric ratio of $2: 3$.

\section{Experimental}

\subsection{Materials and Measurements}

All reagents for the syntheses were purchased from commercial sources and used as received, except for the starting potassium salt, $\mathrm{K}_{3}\left[\mathrm{Cr}\left(\mathrm{C}_{2} \mathrm{O}_{4}\right)_{3}\right] \cdot 3 \mathrm{H}_{2} \mathrm{O}$, which was synthesized according to the literature [17]. Microanalyses (carbon and hydrogen) were performed on a Vario EL (Heraeus) analyzer. The FT-IR spectrum was recorded from $\mathrm{KBr}$ pellets in the range of $4000-400 \mathrm{~cm}^{-1}$ on a Perkin-Elmer spectrometer. The UV-Vis spectrum was obtained on a Perkin-Elmer Lambda 900 spectrophotometer in water at room temperature within the range $300-700 \mathrm{~nm}$. The chemical analysis was obtained using Energy Dispersive X-ray Spectroscopy (EDX), with a JDX-7000F X-ray spectrometer. TGA experiments were performed with a Mettler Toledo TGA/ SDTA 851 thermal analyzer, heated from room temperature to $600^{\circ} \mathrm{C}$ under nitrogen gas with a heating rate of $10^{\circ} \mathrm{C} / \mathrm{min}$. The melting points were measured using an Electrothermal 9100 apparatus.

\subsection{Synthesis of $\left\{\left[\left(\mathrm{H}_{2} \mathrm{O}\right)_{2} \mathrm{~K}\left(\mu-\mathrm{H}_{2} \mathrm{O}\right) \mathrm{Sr}\right] @\left[\mathrm{Cr}\left(\mathrm{C}_{2} \mathrm{O}_{4}\right)_{3}\right]\right\}_{\mathrm{n}}$}

The title compound was obtained by metathesis from the potassium salt as follows: $\mathrm{K}_{3}\left[\mathrm{Cr}_{2}\left(\mathrm{C}_{2} \mathrm{O}_{4}\right)_{3}\right] \cdot 3 \mathrm{H}_{2} \mathrm{O}(0.98 \mathrm{~g}$, $2 \mathrm{mmol})$ was dissolved in $50 \mathrm{~mL}$ of water. Simultaneously, an aqueous solution $(30 \mathrm{~mL})$ of $\mathrm{SrCl}_{2} \cdot 6 \mathrm{H}_{2} \mathrm{O}(0.80 \mathrm{~g}$, $3 \mathrm{mmol}$ ) was prepared and subsequently added in successive small portions into the $\mathrm{K}_{3}\left[\mathrm{Cr}_{2}\left(\mathrm{C}_{2} \mathrm{O}_{4}\right)_{3}\right] \cdot 3 \mathrm{H}_{2} \mathrm{O}$ one. The resulting violet mixture was stirred at $333 \mathrm{~K}$ for 1 hour and then filtered off. The filtrate was allowed to evaporate at room temperature. After a few weeks, violet needle crystals suitable for X-ray diffraction were isolated by filtration, and dried in air. Yield: $0.82 \mathrm{~g}(85.5 \%)$. M. p.: $>240^{\circ} \mathrm{C}$. Anal. Calcd. for $\mathrm{C}_{6} \mathrm{H}_{4} \mathrm{CrKO}_{14} \mathrm{Sr}$ (478.81 $\left.\mathrm{g} \cdot \mathrm{mol}^{-1}\right)$ : C, 15.05; H, 0.84\%. Found: C, 14.96; H, 0.79\%. IR (KBr disk, $\left.\mathrm{cm}^{-1}\right): v=3449(\mathrm{w}), 1708(\mathrm{~m})$, 1672 (s), 1419 (s), 1277 (s), 907 (w), 853 (s), 806 (s), 543 (s), 477 (s). UV-Vis ( $\mathrm{H}_{2} \mathrm{O}$ solution, nm): $417,569$.

\subsection{X-Ray Crystallography}

A violet crystal with approximate dimensions $0.281 \times 0.085 \times 0.038 \mathrm{~mm}^{3}$ was selected under ambient condi- 
tions and attached to the tip of a nylon loop. It was mounted in a stream of cold nitrogen at 100 (1) K and centered in the X-ray beam by using a video camera. The crystal evaluation and data collection were performed on a Bruker QuazarSMART APEXII diffractometer with $\operatorname{MoK}_{\alpha}(\lambda=0.71073 \AA)$ radiation. The program SMART [18] was used for collecting frames of data, indexing reflections, and determining lattice parameters, SAINT [18] for integration of the intensity of reflections and scaling, SADABS [19] for absorption corrections, and SHELXTL [20] [21] for space group and structure determination and least-squares refinements on $F^{2}$. The structure was solved by direct methods using the program SHELXS-97 [22] and refined by full-matrix least-squares methods against $F^{2}$ with SHELXL-97 [22]. All non-hydrogen atoms were refined with anisotropic displacement coefficients. All hydrogen atoms were included in the structure factor calculation at idealized positions and were allowed to ride on the neighboring atoms with relative isotropic displacement coefficients. The figures have been generated using Diamond 3.1e software [23]. Crystallographic data and refinement parameters are listed in Table 1. Selected bond distances and bond angles are given in Table 2.

\section{Table 1. Crystal data and structure refinement parameters for compound $\mathbf{1 .}$}

\begin{tabular}{|c|c|}
\hline Empirical Formula & $\mathrm{C}_{6} \mathrm{H}_{4} \mathrm{CrKO}_{14} \mathrm{Sr}$ \\
\hline Formula weight & 478.81 \\
\hline Temperature (K) & $100(1)$ \\
\hline Wavelength $(\AA)$ & 0.71073 \\
\hline Crystal system & Orthorhombic \\
\hline Space group & Fdd2 \\
\hline$a(\AA)$ & $14.110(4)$ \\
\hline$b(\AA)$ & $36.074(11)$ \\
\hline$c(\AA)$ & $11.034(3)$ \\
\hline$\alpha\left(^{\circ}\right)$ & 90 \\
\hline$\beta\left({ }^{\circ}\right)$ & 90 \\
\hline$\gamma\left({ }^{\circ}\right)$ & 90 \\
\hline Volume $\left(\AA^{3}\right)$ & $5616(3)$ \\
\hline$Z$ & 16 \\
\hline$D_{\text {calc }}\left(\mathrm{g} / \mathrm{cm}^{3}\right)$ & 2.265 \\
\hline Absorption coefficient $\left(\mathrm{mm}^{-1}\right)$ & 4.944 \\
\hline$F(000)$ & 3728.0 \\
\hline Crystal size (mm) & $0.281 \times 0.085 \times 0.038$ \\
\hline $2 \theta$ Range for data collection $\left(^{\circ}\right)$ & $2.258-59.906$ \\
\hline Index ranges & $-19 \leq \mathrm{h} \leq 19 ;-50 \leq \mathrm{k} \leq 50 ;-15 \leq 1 \leq 15$ \\
\hline Reflections collected & 36173 \\
\hline Independent reflections $\left(R_{\text {int }} ; R_{\text {sigma }}\right)$ & $4070(0.0399 ; 0.0214)$ \\
\hline Absorption correction & Semi-empirical \\
\hline Max. and min. transmission & 0.834 and 0.337 \\
\hline Refinement method & Full-matrix least squares on $F^{2}$ \\
\hline Data/restraints/parameters & $4070 / 7 / 235$ \\
\hline Goodness-of-fit on $F^{2}$ & 1.086 \\
\hline Final $R$ indices $[I>2 \operatorname{sigma}(I)]$ & $R_{1}=0.0293, w R_{2}=0.0720$ \\
\hline$R$ indices (all data) & $R_{1}=0.0300, w R_{2}=0.0723$ \\
\hline Largest diff. peak and hole $\left(\mathrm{e} \AA^{-3}\right)$ & 1.19 and -0.68 \\
\hline Flack parameter & $0.001(3)$ \\
\hline
\end{tabular}


Table 2. Selected bond lengths $[\AA]$ and angles $\left[{ }^{\circ}\right]$ for $\mathbf{1}$.

\begin{tabular}{|c|c|c|c|}
\hline \multicolumn{2}{|c|}{ Bond Lengths } & \multicolumn{2}{|c|}{ Bond Angles } \\
\hline $\mathrm{Sr}^{(1)}-\mathrm{O}^{(2) 1}$ & $2.625(4)$ & $\mathrm{O}^{(2) 1}-\mathrm{Sr}^{(1)}-\mathrm{O}^{(4) 1}$ & $63.29(11)$ \\
\hline $\mathrm{Sr}^{(1)}-\mathrm{O}^{(4)}$ & $2.656(3)$ & $\mathrm{O}^{(2) 1}-\mathrm{Sr}^{(1)}-\mathrm{O}^{(4)}$ & $72.98(11)$ \\
\hline $\mathrm{Sr}^{(1)}-\mathrm{O}^{(4) 1}$ & $2.664(3)$ & $\mathrm{O}^{(4)}-\mathrm{Sr}^{(1)}-\mathrm{O}^{(4) 1}$ & $115.13(11)$ \\
\hline $\mathrm{Sr}^{(1)}-\mathrm{O}^{(6) 2}$ & $2.664(4)$ & $\mathrm{O}^{(2) 1}-\mathrm{Sr}^{(1)}-\mathrm{O}^{(6) 2}$ & $132.21(11)$ \\
\hline $\mathrm{Sr}^{(1)}-\mathrm{O}^{(8) 2}$ & $2.688(3)$ & $\mathrm{O}^{(2) 1}-\mathrm{Sr}^{(1)}-\mathrm{O}^{(8) 2}$ & $122.97(11)$ \\
\hline $\mathrm{Sr}^{(1)}-\mathrm{O}^{(10) 3}$ & $2.638(3)$ & $\mathrm{O}^{(2) 1}-\mathrm{Sr}^{(1)}-\mathrm{O}^{(10) 3}$ & $70.95(12)$ \\
\hline $\mathrm{Sr}^{(1)}-\mathrm{O}^{(12) 3}$ & $2.628(3)$ & $\mathrm{O}^{(2) 1}-\mathrm{Sr}^{(1)}-\mathrm{O}^{(12) 3}$ & $69.38(12)$ \\
\hline $\mathrm{Sr}^{(1)}-\mathrm{O}^{(13)}$ & $2.653(4)$ & $\mathrm{O}^{(2) 1}-\mathrm{Sr}^{(1)}-\mathrm{O}^{(13)}$ & $126.73(12)$ \\
\hline $\mathrm{Cr}^{(1)}-\mathrm{O}^{(1)}$ & $1.978(3)$ & $\mathrm{O}^{(5)}-\mathrm{Cr}^{(1)}-\mathrm{O}^{(1)}$ & $172.34(14)$ \\
\hline $\mathrm{Cr}^{(1)}-\mathrm{O}^{(3)}$ & $1.973(3)$ & $\mathrm{O}^{(3)}-\mathrm{Cr}^{(1)}-\mathrm{O}^{(7)}$ & $96.60(14)$ \\
\hline $\mathrm{Cr}^{(1)}-\mathrm{O}^{(5)}$ & $1.976(4)$ & $\mathrm{O}^{(1)}-\mathrm{Cr}^{(1)}-\mathrm{O}^{(5)}$ & $93.00(14)$ \\
\hline $\mathrm{Cr}^{(1)}-\mathrm{O}^{(7)}$ & $1.978(3)$ & $\mathrm{O}^{(9)}-\mathrm{Cr}^{(1)}-\mathrm{O}^{(7)}$ & $170.97(14)$ \\
\hline $\mathrm{Cr}^{(1)}-\mathrm{O}^{(9)}$ & $1.971(3)$ & $\mathrm{O}^{(9)}-\mathrm{Cr}^{(1)}-\mathrm{O}^{(1)}$ & $93.39(15)$ \\
\hline $\mathrm{Cr}^{(1)}-\mathrm{O}^{(11)}$ & $1.986(3)$ & $\mathrm{O}^{(3)}-\mathrm{Cr}^{(1)}-\mathrm{O}^{(11)}$ & $171.42(14)$ \\
\hline $\mathrm{K}^{(1)}-\mathrm{O}^{(9) 4}$ & $2.770(3)$ & $\mathrm{O}^{(9)}-\mathrm{K}^{(1)}-\mathrm{O}^{(13) 4}$ & $86.85(10)$ \\
\hline $\mathrm{K}^{(1)}-\mathrm{O}^{(9)}$ & $2.770(3)$ & $\mathrm{O}^{(9)}-\mathrm{K}^{(1)}-\mathrm{O}^{(10)}$ & $45.09(9)$ \\
\hline $\mathrm{K}^{(1)}-\mathrm{O}^{(10)}$ & $3.007(3)$ & $\mathrm{O}^{(13)}-\mathrm{K}^{(1)}-\mathrm{O}^{(9) 4}$ & $139.83(15)$ \\
\hline $\mathrm{K}^{(1)}-\mathrm{O}^{(10) 4}$ & $3.007(3)$ & $\mathrm{O}^{(13) 4}-\mathrm{K}^{(1)}-\mathrm{O}^{(10) 4}$ & $140.39(17)$ \\
\hline $\mathrm{K}^{(1)}-\mathrm{O}^{(13) 4}$ & $2.876(4)$ & $\mathrm{O}^{(9) 4}-\mathrm{K}^{(1)}-\mathrm{O}^{(13) 4}$ & $86.85(10)$ \\
\hline $\mathrm{K}^{(1)}-\mathrm{O}^{(13)}$ & $2.876(4)$ & $\mathrm{O}^{(9) 4}-\mathrm{K}^{(1)}-\mathrm{O}^{(13)}$ & $115.12(10)$ \\
\hline $\mathrm{K}^{(1)}-\mathrm{O}^{(14) 4}$ & $2.889(8)$ & $\mathrm{O}^{(14) 4}-\mathrm{K}^{(1)}-\mathrm{O}^{(10)}$ & $143.28(16)$ \\
\hline $\mathrm{K}^{(1)}-\mathrm{O}^{(14)}$ & $2.889(8)$ & $\mathrm{O}^{(13) 4}-\mathrm{K}^{(1)}-\mathrm{O}^{(14)}$ & $104.64(17)$ \\
\hline $\mathrm{K}^{(2)}-\mathrm{O}^{(1) 5}$ & $2.728(4)$ & $\mathrm{O}^{(1) 5}-\mathrm{K}^{(2)}-\mathrm{O}^{(15)}$ & $101.9(2)$ \\
\hline $\mathrm{K}^{(2)}-\mathrm{O}^{(2) 5}$ & $2.892(4)$ & $\mathrm{O}^{(15)}-\mathrm{K}^{(2)}-\mathrm{O}^{(2) 5}$ & $120.1(2)$ \\
\hline $\mathrm{K}^{(2)}-\mathrm{O}^{(5)}$ & $2.810(4)$ & $\mathrm{O}^{(15)}-\mathrm{K}^{(2)}-\mathrm{O}^{(5)}$ & $138.0(2)$ \\
\hline $\mathrm{K}^{(2)}-\mathrm{O}^{(6)}$ & $2.990(4)$ & $\mathrm{O}^{(15)}-\mathrm{K}^{(2)}-\mathrm{O}^{(6)}$ & $124.5(2)$ \\
\hline $\mathrm{K}^{(2)}-\mathrm{O}^{(14) 4}$ & $1.922(8)$ & $\mathrm{O}^{(14) 4}-\mathrm{K}^{(2)}-\mathrm{O}^{(5)}$ & $69.7(2)$ \\
\hline $\mathrm{K}^{(2)}-\mathrm{O}^{(14)}$ & $2.753(8)$ & $\mathrm{O}^{(14) 4}-\mathrm{K}^{(2)}-\mathrm{O}^{(6)}$ & $112.3(3)$ \\
\hline $\mathrm{K}^{(2)}-\mathrm{O}^{(15)}$ & $2.716(10)$ & $\mathrm{O}^{(15)}-\mathrm{K}^{(2)}-\mathrm{O}^{(14)}$ & $77.0(2)$ \\
\hline $\mathrm{K}^{(2)}-\mathrm{K}^{(2) 4}$ & $2.214(4)$ & & \\
\hline
\end{tabular}

Symmetry transformations used to generate equivalent atoms: ${ }^{1} 1 / 4+\mathrm{X}, 5 / 4-\mathrm{Y}, 1 / 4+\mathrm{Z} ;{ }^{2} 1 / 4+\mathrm{X}, 5 / 4-\mathrm{Y},-3 / 4+\mathrm{Z} ;{ }^{3} 3 / 4-\mathrm{X}, 1 / 4+\mathrm{Y}$, $-1 / 4+\mathrm{Z} ;{ }^{4} 1-\mathrm{X}, 1-\mathrm{Y},+\mathrm{Z} ;{ }^{5} 1 / 2+\mathrm{X},+\mathrm{Y}, 1 / 2+\mathrm{Z}$.

\section{Results and Discussion}

\subsection{Formation of $\left\{\left[\left(\mathrm{H}_{2} \mathrm{O}\right)_{2} \mathrm{~K}\left(\mu-\mathrm{H}_{2} \mathrm{O}\right) \mathrm{Sr}\right] @\left[\mathrm{Cr}\left(\mathrm{C}_{2} \mathrm{O}_{4}\right)_{3}\right]\right\}_{\mathrm{n}}$ (1)}

Our original attempt aimed at synthesizing the heterometallic neutral polynuclear complex, $\left\{\mathrm{Sr}_{3}\left[\mathrm{Cr}^{\mathrm{III}}\left(\mathrm{C}_{2} \mathrm{O}_{4}\right)_{3}\right]_{2}\right\} \cdot \mathrm{nH}_{2} \mathrm{O}$ with the ionic ratio of $3 \mathrm{Sr}^{\mathrm{II}}$ vs. $2 \mathrm{Cr}^{\mathrm{III}}$, analog of the well-documented $\left\{\mathrm{Ba}_{6}\left(\mathrm{H}_{2} \mathrm{O}\right)_{17}\left[\mathrm{M}^{\mathrm{III}}\left(\mathrm{C}_{2} \mathrm{O}_{4}\right)_{3}\right]_{4}\right\} \cdot 7 \mathrm{H}_{2} \mathrm{O}(\mathrm{M}=\mathrm{Cr}$; $\mathrm{Fe}$ ) compounds [10] [11]. Unexpectedly, the tripotassium tris(oxalato)chromate(III) salt, $\mathrm{K}_{3}\left[\mathrm{Cr}\left(\mathrm{C}_{2} \mathrm{O}_{4}\right)_{3}\right] \cdot 3 \mathrm{H}_{2} \mathrm{O}$, exchanged only two of its three potassium ions for one strontium(II) ion, yielding the air stable heterometallic neutral trinuclear complex, $\left\{\left[\left(\mathrm{H}_{2} \mathrm{O}\right)_{2} \mathrm{~K}\left(\mu-\mathrm{H}_{2} \mathrm{O}\right) \mathrm{Sr}\right] @\left[\mathrm{Cr}\left(\mathrm{C}_{2} \mathrm{O}_{4}\right)_{3}\right]\right\}_{\mathrm{n}}(\mathbf{1})$. The competition between $\mathrm{K}^{+}$and $\mathrm{Sr}^{2+}$ cations appears as an important point to prevent formation of the expected $\mathrm{Sr}(\mathrm{II}) / \mathrm{Cr}(\mathrm{III})$-oxalate coordination polymer, in line with the identical coordination number (8) of $\mathrm{K}^{+}$and of $\mathrm{Sr}^{2+}$ ions in the title compound. Using $\mathrm{Ba}^{2+}$ in lieu of $\mathrm{Sr}^{2+}$ ions, a total exchange of three potassium cations was observed, demonstrating, therefore, a more pronounced affinity of $\mathrm{Ba}^{2+}$ ions to bind tris(oxalato)metalate(III) anions [10] [11]. Efforts were taken to better understand the formation of $\mathbf{1}$ by carrying out two other syntheses with the $\mathrm{K}_{3}\left[\mathrm{Cr}\left(\mathrm{C}_{2} \mathrm{O}_{4}\right)_{3}\right] \cdot 3 \mathrm{H}_{2} \mathrm{O}: \mathrm{SrCl}_{2}$ stoichiometric ratios of 1:1 and 1:2. As expected, the same compound 1 was obtained, different only in purity and yield, the maximum yield being $89 \%$ with the 1:1 ratio. From the above results, it is evident that, irrespective to the stoichiometric ratio of reagents, the title compound is readily formed if $\mathrm{K}_{3}\left[\mathrm{Cr}\left(\mathrm{C}_{2} \mathrm{O}_{4}\right)_{3}\right] \cdot 3 \mathrm{H}_{2} \mathrm{O}$ and $\mathrm{SrCl}_{2}$ are combined. The possible formation mechanisms producing compound $\mathbf{1}$ are summarized in Scheme 1. 
(i) $\mathrm{K}_{3}\left[\mathrm{Cr}\left(\mathrm{C}_{2} \mathrm{O}_{4}\right)_{3}\right] \cdot 3 \mathrm{H}_{2} \mathrm{O}+\mathrm{SrCl}_{2}$

(ii) $\mathrm{K}_{3}\left[\mathrm{Cr}\left(\mathrm{C}_{2} \mathrm{O}_{4}\right)_{3}\right] \cdot 3 \mathrm{H}_{2} \mathrm{O}+3 / 2 \mathrm{SrCl}_{2}$

$\left\{\left[\left(\mathrm{H}_{2} \mathrm{O}\right)_{2} \mathrm{~K}\left(\mu-\mathrm{H}_{2} \mathrm{O}\right) \mathrm{Sr}\right] @\left[\mathrm{Cr}\left(\mathrm{C}_{2} \mathrm{O}_{4}\right)_{3}\right]\right\}_{\mathrm{n}}+2 \mathrm{KCl}$

(iii) $\mathrm{K}_{3}\left[\mathrm{Cr}\left(\mathrm{C}_{2} \mathrm{O}_{4}\right)_{3}\right] \cdot 3 \mathrm{H}_{2} \mathrm{O}+2 \mathrm{SrCl}_{2}$

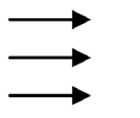

$\left\{\left[\left(\mathrm{H}_{2} \mathrm{O}\right)_{2} \mathrm{~K}\left(\mu-\mathrm{H}_{2} \mathrm{O}\right) \mathrm{Sr}\right] @\left[\mathrm{Cr}\left(\mathrm{C}_{2} \mathrm{O}_{4}\right)_{3}\right]\right\}_{\mathrm{n}}+2 \mathrm{KCl}+1 / 2 \mathrm{SrCl}_{2}$

$\left\{\left[\left(\mathrm{H}_{2} \mathrm{O}\right)_{2} \mathrm{~K}\left(\mu-\mathrm{H}_{2} \mathrm{O}\right) \mathrm{Sr}\right] @\left[\mathrm{Cr}\left(\mathrm{C}_{2} \mathrm{O}_{4}\right)_{3}\right]_{\mathrm{n}}+2 \mathrm{KCl}+\mathrm{SrCl}_{2}\right.$

Scheme 1. The possible formation mechanisms of compound $\mathbf{1}$.

\subsection{Energy Dispersive X-Ray Analysis}

Results from the Energy Dispersive X-ray Spectroscopy (EDX) analyses of $\mathbf{1}$ are shown in Figure 1. It is observed in this EDX spectrum the presence of chemical elements $\mathrm{O}, \mathrm{K}, \mathrm{Sr}$ and $\mathrm{Cr}$, suggesting clearly the success in the preparation of compound $\mathbf{1}$.

\subsection{Infrared Spectrum}

The IR spectrum exhibits weak absorption bands centered at $3449 \mathrm{~cm}^{-1}$ and attributable to the well-known $v_{\mathrm{O}-\mathrm{H}}$ vibrations of the $\mathrm{H}_{2} \mathrm{O}$ molecules that are coordinated to the $\mathrm{K}^{+}$and $\mathrm{Sr}^{2+}$ sites. The band at $1700 \mathrm{~cm}^{-1}$ is assigned to $v_{\mathrm{C}=\mathrm{O}}$ whereas those at $1419 \mathrm{~cm}^{-1}$ are attributed to $v_{\mathrm{O}-\mathrm{C}=\mathrm{O}}$ [24]. The sharp peaks at $1277 \mathrm{~cm}^{-1}$ and $907 \mathrm{~cm}^{-1}$ may be tentatively assigned to the $v_{\mathrm{C}-\mathrm{O}}$ and $v_{\mathrm{C}-\mathrm{C}}$ vibrations [24], respectively. Medium to weak bands appearing in the region below $600 \mathrm{~cm}^{-1}$ may be attributed to vibrations within the coordination spheres around the metallic centers. These results are, in fact, consistent with the presence of $\left[\mathrm{Cr}\left(\mathrm{C}_{2} \mathrm{O}_{4}\right)_{3}\right]^{3-}$ and $\mathrm{H}_{2} \mathrm{O}$ in the material concerned.

\subsection{UV-Vis Spectrum}

The ultraviolet-visible spectrum in aqueous solution showed peaks at 417 and $569 \mathrm{~nm}$ attributed to the spin-allowed ${ }^{4} \mathrm{~A}_{2 \mathrm{~g}}(\mathrm{~F}) \rightarrow{ }^{4} \mathrm{~T}_{1 \mathrm{~g}}(\mathrm{~F})$ and ${ }^{4} \mathrm{~A}_{2 \mathrm{~g}}(\mathrm{~F}) \rightarrow{ }^{4} \mathrm{~T}_{2 \mathrm{~g}}(\mathrm{~F})$ transitions, respectively, within the octahedral complex anion $\left[\mathrm{Cr}\left(\mathrm{C}_{2} \mathrm{O}_{4}\right)_{3}\right]^{3-}$ contained in $\mathbf{1}$. It is obvious that the present electronic absorption spectrum is virtually superimposable with that reported [10] [12] [13] [25] since the spectral information thus obtained solely relate to the $\left[\mathrm{Cr}\left(\mathrm{C}_{2} \mathrm{O}_{4}\right)_{3}\right]^{3-}$ species.

\subsection{Thermal Analysis}

The thermal behavior of $\mathbf{1}$ has been studied by thermogravimetric analysis (TGA) and differential thermal analysis (DTA) in the temperature range of $25^{\circ} \mathrm{C}$ to $600^{\circ} \mathrm{C}$ at a heating rate of $10^{\circ} \mathrm{C}$ per minute under nitrogen atmosphere. TGA and DTA curves are depicted in Figure 2. The overall TGA curve consists of two-step weight loss process. The first step between $80^{\circ} \mathrm{C}$ and $150^{\circ} \mathrm{C}$ corresponds to a weight loss of $11.4 \%$ (calc. $11.3 \%$ ) which is due to release of the three coordinated water molecules. During the second step, beyond $150^{\circ} \mathrm{C}$, a gradual decomposition of the crystal network takes place with formation of a final residue which is proved to be a mixture of $\mathrm{SrCrO}_{4}$ and $\mathrm{K}_{2} \mathrm{CO}_{3}$ compounds.

\subsection{Crystal Structure}

The molecular structure of $\mathbf{1}$ has been determined by X-ray study, which shows that it crystallizes in orthorhombic chiral space group Fdd2 with three-dimensinal arrangement. As depicted in Figure 3, the asymmetric unit of 1 consists of one cationic motif-formally $\left[\left(\mathrm{H}_{2} \mathrm{O}\right)_{2} \mathrm{~K}\left(\mu-\mathrm{H}_{2} \mathrm{O}\right) \mathrm{Sr}\right]^{3+}$, and one anionic $\left[\mathrm{Cr}\left(\mathrm{C}_{2} \mathrm{O}_{4}\right)_{3}\right]^{3-}$ entity. The anionic building stone, $\left[\mathrm{Cr}\left(\mathrm{C}_{2} \mathrm{O}_{4}\right)_{3}\right]^{3-}$, functions as a metalloligand or else, as an internetting bridge. Hence, this internetting bridge interconnects, across its $\mathrm{O}$ atoms, the independent sites $\mathrm{K}, \mathrm{Sr} 1$ and $\mathrm{Cr} 1$ into a three-dimensional polymeric lattice network.

Two independent $\mathrm{K}$ centers ( $\mathrm{K} 1$ and $\mathrm{K} 2$ ) are eight-coordinate both by $\mathrm{H}_{2} \mathrm{O}$ and oxalate ligands and are present $50 \%$ in the asymmetric unit. Atom K1 is coordinated to two water molecules (OW13 and OW14). Atom K2 is coordinated to two water molecules (OW14 and OW15). The water molecules OW13 and O14W bridge the K1 and $\mathrm{Sr} 1$ centers and the K1 and K2 centers, respectively. The water molecule OW15 belongs solely to the K2 center. A molecular drawing of compound $\mathbf{1}$ with complete coordination spheres of the metal atoms is shown in Figure 4 and selected geometrical parameters are presented in Table 2. As can be seen from Figure 4, the eighth coordination of the K2 center is completed by an unusual short K2 - K2 ${ }^{4}$ metallic bond of 2.214 (4) $\AA$. All the K-O bond lengths fit well within the range of previous results [26]. 


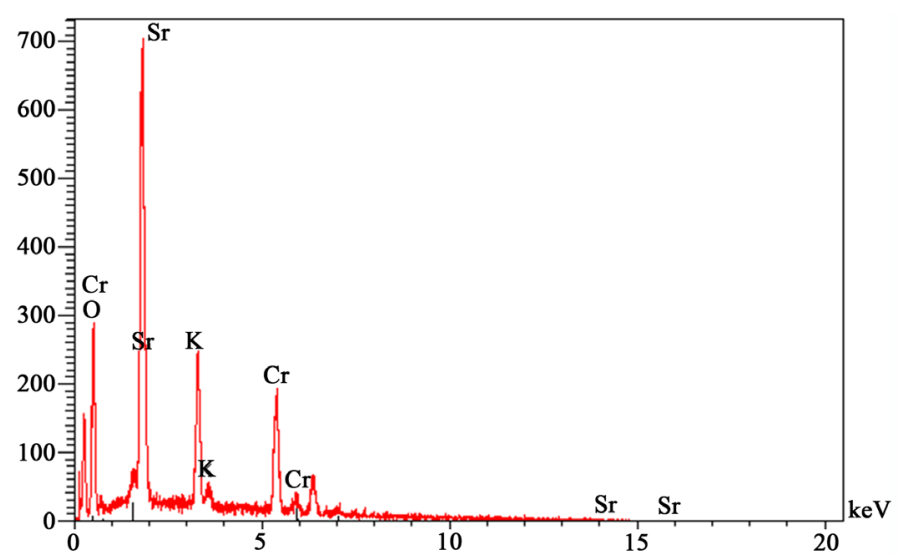

Figure 1. EDX analysis of compound 1 showing the nature of its different chemical elements.

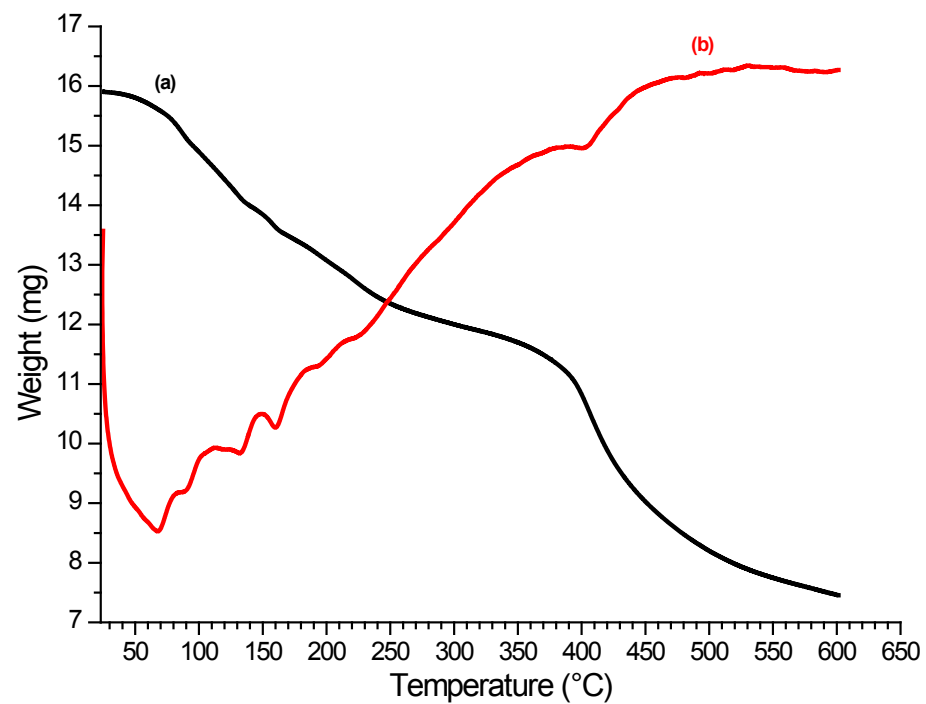

Figure 2. TGA (curve (a)) and DTA (curve (b)) of compound 1.

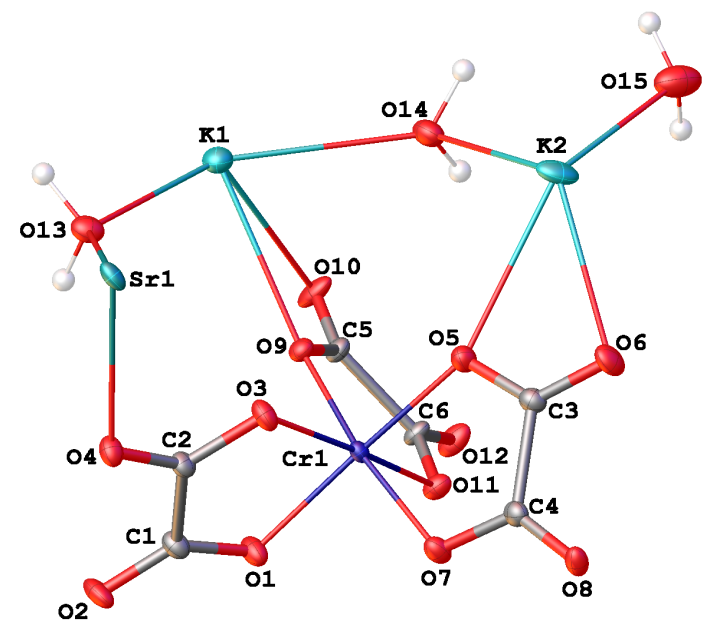

Figure 3. A molecular drawing of the asymmetric unit of compound 1 shown with $50 \%$ probability ellipsoids. Atoms K1 and K2 are present $50 \%$ of the time. 


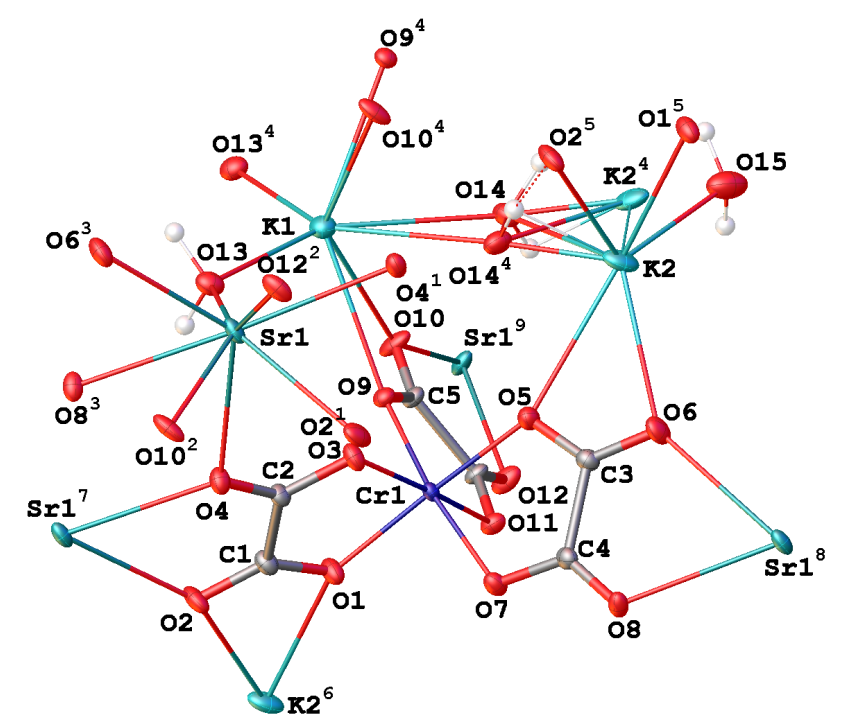

\begin{abstract}
Figure 4. A molecular drawing of compound 1 shown with $50 \%$ probability ellipsoids. The coordination spheres of the metal atoms are completed. Atoms K1 and K2 are present $50 \%$ of the time. Symmetry codes: $\$ 11 / 4+X, 5 / 4-Y, 1 / 4+Z, \$ 23 / 4-X, 1 / 4+Y,-1 / 4+Z, \$ 31 / 4+$ $\mathrm{X}, 5 / 4-\mathrm{Y},-3 / 4+\mathrm{Z}, \$ 41-\mathrm{X}, 1-\mathrm{Y},+\mathrm{Z}, \$ 51 / 2+\mathrm{X},+\mathrm{Y}, 1 / 2+\mathrm{Z}, \$ 6-1 / 2+\mathrm{X},+\mathrm{Y},-1 / 2+\mathrm{Z}$, $\$ 7-1 / 4+X, 5 / 4-Y,-1 / 4+Z, \$ 8-1 / 4+X, 5 / 4-Y, 3 / 4+Z, \$ 93 / 4-X,-1 / 4+Y, 1 / 4+Z$.
\end{abstract}

The Sr1 site experiences also eight-coordinate coordination sphere, involving one chelation via the "external" $\mathrm{O}$ atoms $(\mathrm{O} 6, \mathrm{O} 8)$ and to six monodentate linkages, i.e. one across an $\mathrm{O}$ atom of water molecule (OW13) and five across "external" $\mathrm{O}$ atoms $\left(\mathrm{O} 2, \mathrm{O} 4, \mathrm{O} 4{ }^{1}, \mathrm{O} 10, \mathrm{O} 12\right)$. Taking into account the coordination of aqua ligands to $\mathrm{K}$ and $\mathrm{Sr}$ centers, the cationic motif in the asymmetric unit of $\mathbf{1}$ can be formulated $\left[(\mathrm{OW} 15) \mathrm{K} 2_{1 / 2}\left(\mu\right.\right.$-OW14)K $1_{1 / 2}(\mu \text {-OW13)Sr1 }]^{3+}$ or simply $\left[\left(\mathrm{H}_{2} \mathrm{O}\right)_{2} \mathrm{~K}\left(\mu-\mathrm{H}_{2} \mathrm{O}\right) \mathrm{Sr}\right]^{3+}$.

The $\mathrm{Cr} 1$ center is exclusively coordinated by oxalates to produce the well-established helical coordination geometry of $\left[\mathrm{Cr}\left(\mathrm{C}_{2} \mathrm{O}_{4}\right)_{3}\right]^{3-}$ ions. This coordination to chromium occurs across the six "internal" $\mathrm{O}$ atoms $(\mathrm{O} 1$, $\mathrm{O} 3, \mathrm{O} 5, \mathrm{O} 7, \mathrm{O} 9, \mathrm{O} 11$ ), giving rise to $\mathrm{Cr} 1-\mathrm{O}$ bond lengths ranging from 1.971 (3) to 1.983 (6) $\AA$ and O-Cr1-O bond angles ranging from 82.18 (14) to 172.34 (14). These bond lengths and bond angles are in good agreement with those found in other tris(oxalato)metalate(III) complexes [10]-[15] [26].

The packing diagram of compound $\mathbf{1}$ viewed down the crystallographic $c$-axis is shown in Figure 5 . The bulk structure of $\mathbf{1}$ is consolidated by coulombic interactions between the ionic motifs and a three-dimensional network of hydrogen bonding of the type $\mathrm{O}-\mathrm{H} \cdots \mathrm{O}$, with $\mathrm{O} \cdots \mathrm{O}$ distances ranging from 2.626 (14) to 2.898 (8) $\AA$ (Table 3). It should be noted that, to the best of our knowledge, compound 1 constitutes the first chiral, non-hydrated representative of oxalate-based coordination polymers with general formula $\left\{\mathrm{M}(\mathrm{I}) / \mathrm{M}(\mathrm{II}) / \mathrm{M}^{\mathrm{III}}\left(\mathrm{C}_{2} \mathrm{O}_{4}\right)_{3}\right\} \cdot \mathrm{nH}_{2} \mathrm{O}$.

\title{
4. Conclusion
}

We have isolated from aqueous solution at room temperature, a novel trinuclear heterometallic complex of composition $\left\{\left[\left(\mathrm{H}_{2} \mathrm{O}\right)_{2} \mathrm{~K}\left(\mu-\mathrm{H}_{2} \mathrm{O}\right) \mathrm{Sr}\right] @\left[\mathrm{Cr}\left(\mathrm{C}_{2} \mathrm{O}_{4}\right)_{3}\right]\right\}_{\mathrm{n}}(\mathbf{1})$, via a metathesis reaction of $\mathrm{K}_{3}\left[\mathrm{Cr}\left(\mathrm{C}_{2} \mathrm{O}_{4}\right)_{3}\right] \cdot 3 \mathrm{H}_{2} \mathrm{O}$ with $\mathrm{SrCl}_{2}$. The bulk structure of $\mathbf{1}$ is a chiral, 3-D metal-organic framework held together by intermetallic linkages across oxalate and aqua oxygen bridging with extensive hydrogen-bonding interactions stabilizing the crystal packing. Thermal analysis of 1 reveals that it is stable up to $c a .80^{\circ} \mathrm{C}$. Preliminary observations from our laboratory suggest that a well conceived and systematically conducted preparative procedure may be applied generally to fabricate a whole range of homologous members of this promising family of chiral, 3-D metal(I)/metal(II)/metal(III)-oxalate polymers.

\section{Acknowledgements}

The authors are grateful to Dr. Ilia A. Guzei, University of Wisconsin-Madison (USA), for the use of his group 


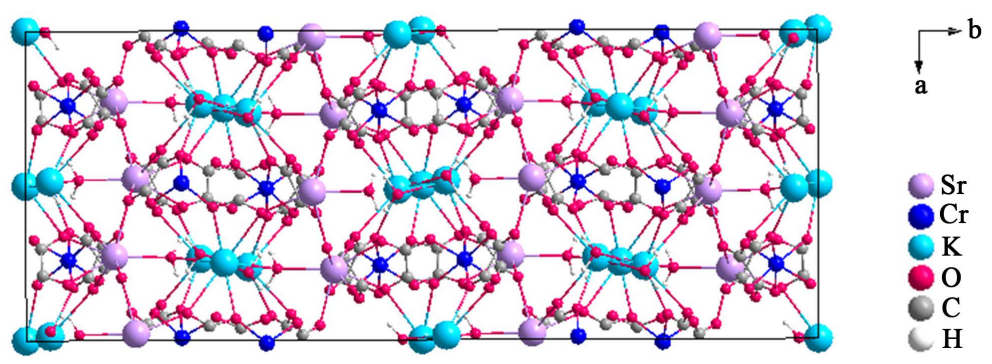

Figure 5. Packing diagram of compound 1 viewed down $c$-axis highlighting the chiral three-dimensional network.

Table 3. Hydrogen bond lengths $[\AA]$ and angles [ $\left.{ }^{\circ}\right]$ for $\mathbf{1}$.

\begin{tabular}{ccccc}
\hline $\mathrm{D}-\mathrm{H} \cdots \mathrm{A}$ & $d(\mathrm{D}-\mathrm{H})$ & $d(\mathrm{H} \cdots \mathrm{A})$ & $d(\mathrm{D} \cdots \mathrm{A})$ & $<(\mathrm{DHA})$ \\
\hline $\mathrm{O}^{(13)}-\mathrm{H}^{(13 \mathrm{~A}) \cdots} \mathrm{O}^{(12) 1}$ & $0.9583(15)$ & $1.803(19)$ & $2.727(5)$ & $161(5)$ \\
$\mathrm{O}^{(14)}-\mathrm{H}^{(14 \mathrm{~A}) \cdots} \mathrm{O}^{(5) 2}$ & 0.96 & 1.95 & $2.799(8)$ & 146.6 \\
$\mathrm{O}^{(14)}-\mathrm{H}^{(14 \mathrm{~B})} \cdots \mathrm{O}^{(2) 3}$ & 0.96 & 1.95 & $2.898(8)$ & 171.8 \\
$\mathrm{O}^{(15)}-\mathrm{H}^{(15 \mathrm{~A}) \cdots \mathrm{O}^{(6) 2}}$ & 0.96 & 1.90 & $2.830(9)$ & 165.0 \\
$\mathrm{O}^{(15)}-\mathrm{H}^{(15 \mathrm{~B}) \cdots \mathrm{O}^{(1) 3}}$ & 0.96 & 1.82 & $2.722(9)$ & 156.1 \\
\hline
\end{tabular}

Symmetry transformations used to generate equivalent atoms (D: donor; A: acceptor): ${ }^{1} 1 / 2-\mathrm{X}, 1-\mathrm{Y},-1 / 2+\mathrm{Z} ;{ }^{2} 1-\mathrm{X}, 1-\mathrm{Y},+\mathrm{Z} ;{ }^{3} 1 / 2$ $-\mathrm{X}, 1-\mathrm{Y}, 1 / 2+\mathrm{Z}$.

X-ray facilities and to Priv.-Doz. Dr. Boniface P. T. Fokwa, Aachen University (Germany), for his help with EDX, thermal and elemental analyses.

\section{References}

[1] Moulton, B. and Zaworotko, M.J. (2001) From Molecules to Crystal Engineering: Supramolecular Isomerism and Polymorphism in Network Solids. Chemical Reviews, 101, 1629-1658. http://dx.doi.org/10.1021/cr9900432

[2] Rao, C.N.R. and Nath, H. (2003) Inorganic Nanotubes. Dalton Transactions, 1-24. http://dx.doi.org/10.1039/b208990b

[3] Pardo, E., Train, C., Boubekeur, K., Gontard, G., Cano, J., Lloret, F., Nakatani, K. and Verdaguer, M. (2012) Topological Versatility of Oxalate-Based Bimetallic One-Dimensional (1D) Compounds Associated with Ammonium Cations. Inorganic Chemistry, 51, 11582-11593. http://dx.doi.org/10.1021/ic3014915

[4] Coronado, E., Galán-Mascarós, J.R., Gómez-García, C.J. and Martínez-Agudo, J.M. (2001) Molecule-Based Magnets Formed by Bimetallic Three-Dimensional Oxalate Networks and Chiral Tris(bipyridyl) Complex Cations. The Series $\left[\mathrm{Z}^{\mathrm{II}}(\mathrm{bpy})_{3}\right]\left[\mathrm{ClO}_{4}\right]\left[\mathrm{M}^{\mathrm{II}} \mathrm{Cr}^{\mathrm{III}}(\mathrm{ox})_{3}\right]\left(\mathrm{Z}^{\mathrm{II}}=\mathrm{Ru}, \mathrm{Fe}, \mathrm{Co}\right.$, and $\mathrm{Ni}$; $\mathrm{M}^{\mathrm{II}}=\mathrm{Mn}, \mathrm{Fe}, \mathrm{Co}, \mathrm{Ni}, \mathrm{Cu}$, and $\mathrm{Zn}$; ox $=$ Oxalate Dianion $)$. Inorganic Chemistry, 40, 113-120. http://dx.doi.org/10.1021/ic0008870

[5] Vaidhyanathan, R., Natarajan, S. and Rao, C.N.R. (2001) Three-Dimensional Yttrium Oxalates Possessing Large Channels. Chemistry of Materials, 13, 185-191. http://dx.doi.org/10.1021/cm000419o

[6] Decurtins, S., Schmalle, H.W., Schneuwly, P., Ensling, J. and Guetlich, P. (1994) A Concept for the Synthesis of 3Dimensional Homo- and Bimetallic Oxalate-Bridged Networks $\left[\mathrm{M}_{2}(\mathrm{ox})_{3}\right]_{\mathrm{n}}$. Structural, Moessbauer, and Magnetic Studies in the Field of Molecular-Based Magnets. Journal of the American Chemical Society, 116, 9521-9528. http://dx.doi.org/10.1021/ja00100a016

[7] Lacroix, P.G., Malfant, I., Bénard, S., Yu, P., Rivière, E. and Nakatani, K. (2001) Hybrid Molecular-Based Magnets Containing Organic NLO Chromophores: A Search toward an Interplay between Magnetic and NLO Behavior. Chemistry of Materials, 13, 441-449. http://dx.doi.org/10.1021/cm001177v

[8] Andrés, R., Brissard, M., Gruselle, M., Train, C., Vaissermann, J., Malézieux, B., Jamet, J.P. and Verdaguer, M. (2001) Rational Design of Three-Dimensional (3D) Optically Active Molecule-Based Magnets: Synthesis, Structure, Optical and Magnetic Properties of $\left\{\left[\mathrm{Ru}(\text { bpy })_{3}\right]^{2+}, \mathrm{ClO}_{4}^{-},\left[\mathrm{Mn}^{\mathrm{II}} \mathrm{Cr}^{\mathrm{III}}(\mathrm{ox})_{3}\right]^{-}\right\}_{n}$ and $\left\{\left[\mathrm{Ru}(\mathrm{bpy})_{2} \text { ppy }\right]^{+},\left[\mathrm{M}^{\mathrm{II}} \mathrm{Cr}^{\mathrm{III}}(\mathrm{ox})_{3}\right]^{-}\right\}_{n}$, with $\mathrm{M}^{\mathrm{Il}}$ $=\mathrm{Mn}^{\mathrm{II}}, \quad \mathrm{Ni}^{\mathrm{II}}$. X-Ray Structure of $\left\{\left[\Delta \mathrm{Ru}(\mathrm{bpy})_{3}\right]^{2+}, \mathrm{ClO}_{4}^{-}, \quad\left[\Delta \mathrm{Mn}^{\mathrm{II}} \Delta \mathrm{Cr}^{\mathrm{III}}(\mathrm{ox})_{3}\right]^{-}\right\}_{n}$ and $\left\{\left[\Lambda \mathrm{Ru}(\mathrm{bpy})_{2} \mathrm{ppy}\right]^{+}\right.$, $\left.\left[\Lambda \mathrm{Mn}^{\mathrm{II}} \Lambda \mathrm{Cr}^{\mathrm{III}}(\mathrm{ox})_{3}\right]^{-}\right\}_{n}$. Inorganic Chemistry, 40, 4633-4640. http://dx.doi.org/10.1021/ic010363f 
[9] Decurtins, S., Schmalle, H.W., Pellaux, R., Schneuwly, P. and Hauser, A. (1996) Chiral, Three-Dimensional Supramolecular Compounds: Homo- and Bimetallic Oxalate- and 1,2-Dithiooxalate-Bridged Networks. A Structural and Photophysical Study. Inorganic Chemistry, 35, 1451-1460. http://dx.doi.org/10.1021/ic950791j

[10] Bélombé, M.M., Nenwa, J., Mbiangué, Y.A., Evina-Nnanga, G., Mbomékallé, I.M., Hey-Hawkins, E., Lönnecke, P. and Majoumo, F. (2003) Unusual Aquation of $\mathrm{Ba}^{2+}$ Ions in the Solid State: Synthesis and X-ray Structural and Spectroscopic Characterization of the Novel Polymeric Complex Salt of Empirical Formula $\left\{\mathrm{Ba}_{6}\left(\mathrm{H}_{2} \mathrm{O}\right)_{17}\left[\mathrm{Cr}(\mathrm{ox})_{3}\right]_{4}\right\} \cdot 7 \mathrm{H}_{2} \mathrm{O}$ (ox = Oxalate Dianion). Dalton Transactions, 2117-2118. http://dx.doi.org/10.1039/b302489j

[11] Makon Ma Houga, N., Dolinar, B.S., Nenwa, J. and Gouet, B. (2014) Synthesis, Crystal Structure and Thermal Behavior of a 3-D Barium(II)/Iron(III)-Oxalate Polymer. Open Journal of Inorganic Chemistry, 4, 21-29. http://dx.doi.org/10.4236/ojic.2014.42004

[12] Bélombé, M.M., Nenwa, J., Mbiangué, Y.A., Gouet, B., Majoumo, F., Hey-Hawkins, E. and Lönnecke, P. (2009) Water-Filled Pseudo-Nanotubes in $\mathrm{Ag}_{11.60} \mathrm{H}_{0.40}\left[\mathrm{Cr}\left(\mathrm{C}_{2} \mathrm{O}_{4}\right)_{3}\right]_{4} \cdot 15 \mathrm{H}_{2} \mathrm{O}$ : Synthesis, Characterization and X-Ray Structure. Inorganica Chimica Acta, 362, 1-4. http://dx.doi.org/10.1016/j.ica.2007.03.003

[13] Bélombé, M.M., Nenwa, J., Tene, T.O. and Fokwa, B.P.T. (2010) Synthesis, X-Ray Structure and Thermal Behavior of Isomorphous Silver-Deficient Channel Lattice Frameworks with General Formula $\left[\left(\mathrm{Ag}_{0.25} / \mathrm{M}_{0.25}\right)\left(\mathrm{H}_{2} \mathrm{O}\right)\right] @\left[\mathrm{Ag}_{2} \mathrm{M}-\right.$ $\left.\left(\mathrm{C}_{2} \mathrm{O}_{4}\right)_{3}\right] \cdot 4 \mathrm{H}_{2} \mathrm{O}\left(\mathrm{M}=\mathrm{Co}^{\mathrm{III}}, \mathrm{Cr}^{\mathrm{III}}\right)$. Global Journal of Inorganic Chemistry, 1, 34-41.

[14] Bélombé, M.M., Nenwa, J., Mbiangué, Y.A., Majoumo, F., Lönnecke, P. and Hey-Hawkins, E. (2009) HydrogenBonded Pillars of Alternating Chiral Complex Cations and Anions: 1. Synthesis, Characterization, X-Ray Structure and Thermal Stability of catena- $\left\{\left[\mathrm{Co}\left(\mathrm{H}_{2} \text { oxado }\right)_{3}\right]\left[\mathrm{Cr}\left(\mathrm{C}_{2} \mathrm{O}_{4}\right)_{3}\right] \cdot 5 \mathrm{H}_{2} \mathrm{O}\right\}$ and of Its Precursor $\left(\mathrm{H}_{3} \mathrm{oxado}\right)-\left[\mathrm{Co}\left(\mathrm{H}_{2} \mathrm{Oxado}\right)_{3}\right]-$ $\left(\mathrm{SO}_{4}\right)_{2} \cdot 2 \mathrm{H}_{2} \mathrm{O}$. Dalton Transactions, 4519-4525. http://dx.doi.org/10.1039/b818793b

[15] Mbiangué, Y.A., Nenwa, J., Bélombé, M.M., Ngoune, J. and Álvarez, E. (2012) Hydrogen-Bonded Pillars of Alternating Chiral Complex Cations and Anions: 2. Synthesis, Characterization and X-ray Structure of Isomorphous catena- $\left\{\left(\mathrm{H}_{3} \mathrm{O}\right)\right.$ $\left.\left[\mathrm{K}\left(\mathrm{H}_{2} \mathrm{O}\right)_{3}\right] @\left[\mathrm{Ni}\left(\mathrm{H}_{2} \mathrm{Oxado}\right)_{3}\right]_{2}\left[\mathrm{Cr}\left(\mathrm{C}_{2} \mathrm{O}_{4}\right)_{3}\right]_{2} \cdot 3 \mathrm{H}_{2} \mathrm{O}\right\}$ and catena- $\left\{\left(\mathrm{H}_{3} \mathrm{O}\right)\left[\mathrm{Li}\left(\mathrm{H}_{2} \mathrm{O}\right)_{3}\right] @\left[\mathrm{Ni}_{2}\left(\mathrm{H}_{2} \mathrm{Oxado}\right)_{3}\right]_{2}\left[\mathrm{Cr}\left(\mathrm{C}_{2} \mathrm{O}_{4}\right)_{3}\right]_{2} \cdot 3 \mathrm{H}_{2} \mathrm{O}\right\}$. ScienceJet, 1, 1-9.

[16] Train, C., Gheorghe, R., Krstic, V., Chamoreau, L.M., Ovanesyan, N.S., Rikken, G.L.J.A., Gruselle, M. and Verdaguer, M. (2008) Strong Magneto-Chiral Dichroism in Enantiopure Chiral Ferromagnets. Nature Materials, 7, 729-734. http://dx.doi.org/10.1038/nmat2256

[17] Bailar Jr., J.C. and Jones, E.M. (1939) Tris(oxalato) Salts. Inorganic Syntheses, 1, 35-38. http://dx.doi.org/10.1002/9780470132326.ch13

[18] SMART \& SAINT Software Reference Manual, Version 6.45. Bruker Analytical X-Ray Systems, Inc., Madison, 2003.

[19] Sheldrick, G.M. (2002) SADABS, Version 2.05. A Software for Empirical Absorption Correction. University of Göttingen, Göttingen.

[20] Sheldrick, G.M. (2000) SHELXTL Version 6.1. Bruker AXS Inc., Madison.

[21] Sheldrick, G.M. (2001) SHELXTL Version 6.12. Bruker AXS Inc., Madison.

[22] Sheldrick, G.M. (1997) SHELXL97 Program for Crystal Structure Refinement. University of Göttingen, Göttingen.

[23] Brandenburg, K. (2005) Diamond, Version 3.1. Crystal Impact GbR, Bonn.

[24] Nakamoto, K. (1997) Infrared Spectra of Inorganic and Coordination Compounds. 5th Edition, John Wiley, New York, 74-77.

[25] Gouet, B., Signé, M., Nenwa, J. and Fokwa, B.P.T. (2013) Synthesis, Crystal Structure and Spectroscopic Characterization of an Oxalato Bridged Silver-Deficient Chromium(III) Salt with Water-Filled Nanochannels. Research Journal of Chemistry and Environment, 17, 57-63.

[26] Masters, V., Gahan, L.R. and Kennard, C.H.L. (1997) Calcium Potassium Tris(oxalato-O $\mathrm{O}^{1}, \mathrm{O}^{2}$ )chromate(III) Pentahydrate. Acta Crystallographica Section C, 53, 1576-1577. http://dx.doi.org/10.1107/S0108270197007762

\section{Supplementary Material}

Detailed crystallographic data in CIF format for this paper were deposited with the Cambridge Crystallographic Data Centre (CCDC-1021676). The data can be obtained free of charge at www.ccdc.cam.ac.uk/conts/retrieving.html [or from Cambridge Crystallographic Data Centre (CCDC), 12 Union Road, Cambridge CB2 IEZ, UK; fax: +44 (0) 1223-336033; e-mail: deposit@ccdc.cam.ac.uk]. 
Scientific Research Publishing (SCIRP) is one of the largest Open Access journal publishers. It is currently publishing more than 200 open access, online, peer-reviewed journals covering a wide range of academic disciplines. SCIRP serves the worldwide academic communities and contributes to the progress and application of science with its publication.

Other selected journals from SCIRP are listed as below. Submit your manuscript to us via either submit@scirp.org or Online Submission Portal.
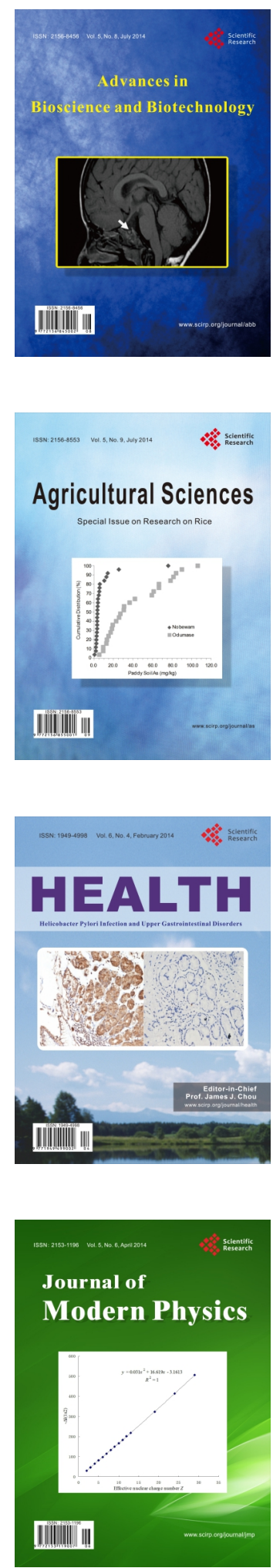
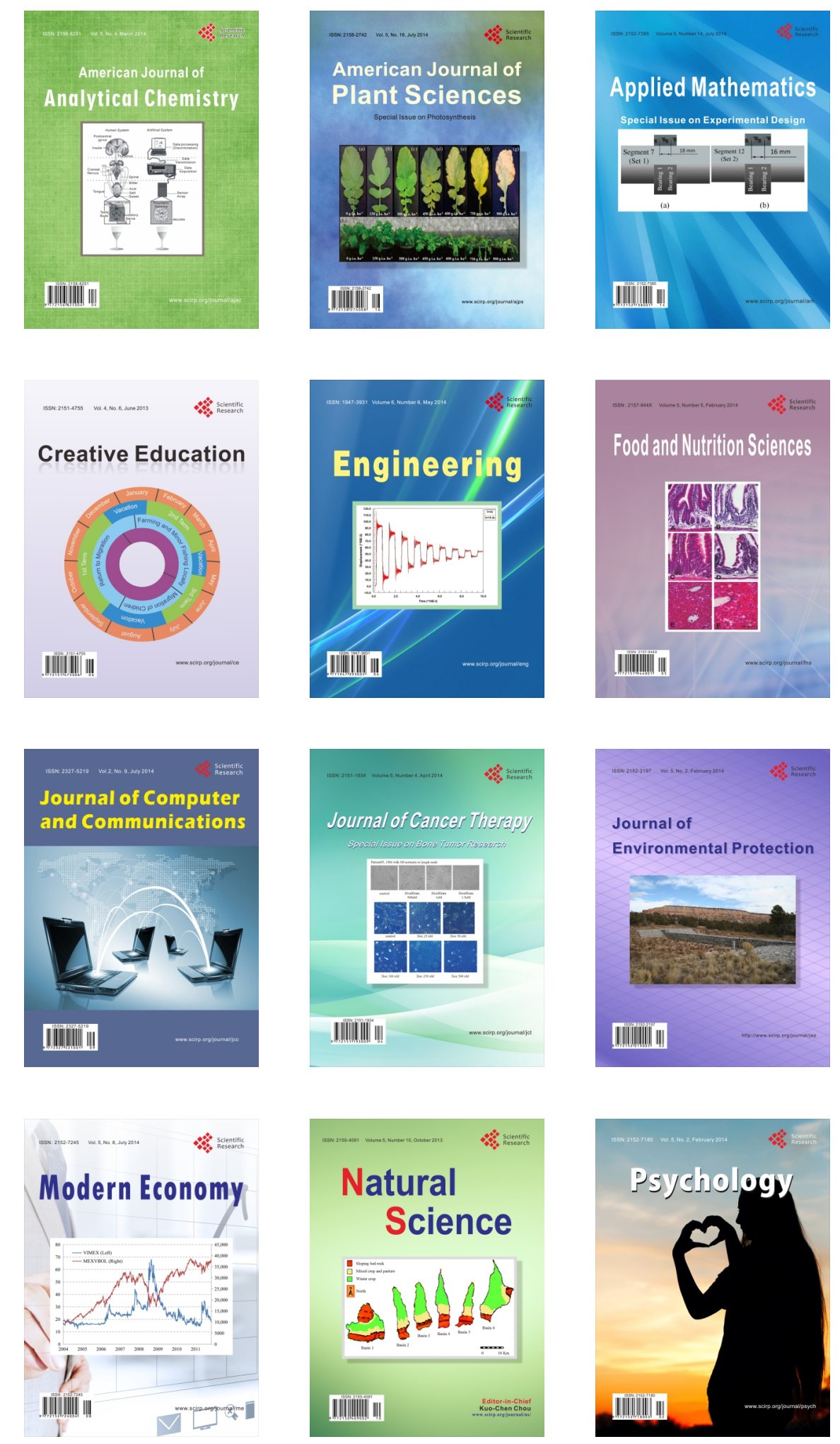